\title{
Nurses defending the autonomy of the elderly at the end of life
}

\author{
Oenfermeiro na defesa da autonomia do idoso na terminalidade da vida \\ El enfermero en la defensa de la autonomía del anciano al final de la vida
}

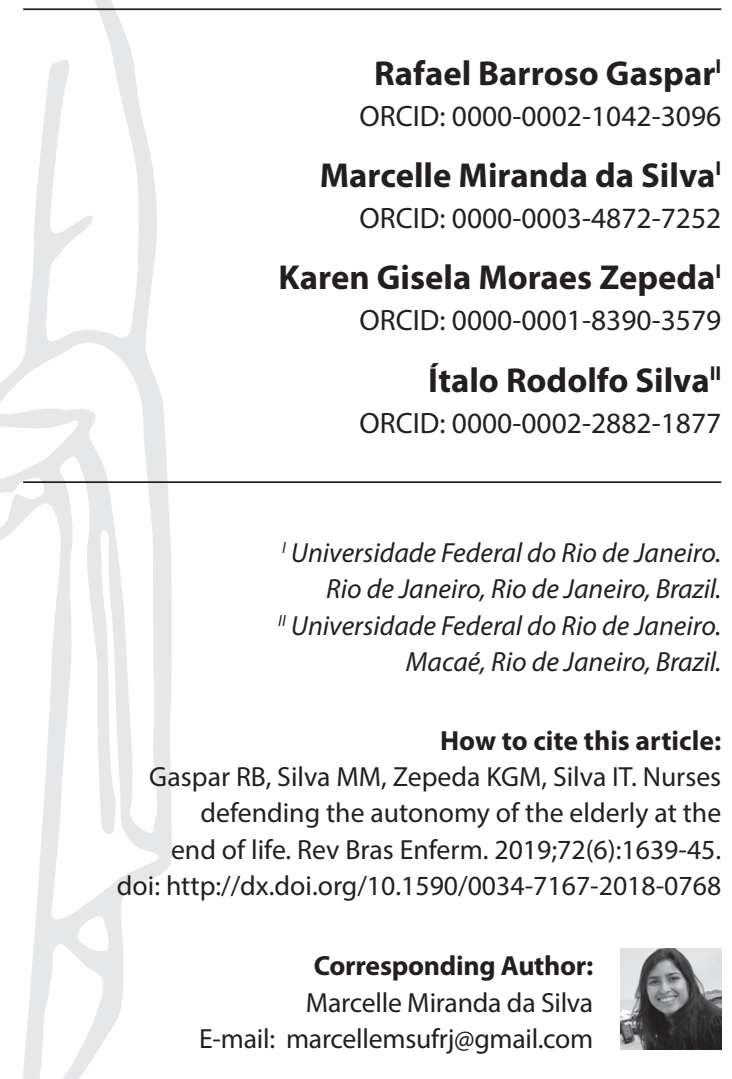

Submission: 10-04-2018 Approval: 02-27-2019

\begin{abstract}
Objective: to understand how nurses deal with the elderly's autonomy at the end of life. Method: qualitative, exploratory study, guided by the Grounded Theory. Ten nurses, eight doctors and 15 nursing technicians were interviewed between November 2016 and May 2017 at a university hospital in Rio de Janeiro/Brazil. Results: nurses deal with the elderly's autonomy in compliance with the code of ethics and exercise leadership in actions and interactions to defend this right, evaluating, guiding and listening to the preferences of the elderly; interacting with the family; and sharing information with the health team. Final considerations: the elderly's autonomy must be ensured in care planning, based on patient-centered communication and developed in the interaction among agents involved in care. The discussion on "Living Wills" Health Care Directives and principles of palliative care must be encouraged.
\end{abstract}

Descriptors: Nursing; Personal Autonomy; Hospice Care; Aged Rights; Chronic Ddisease; Hospitalization.

\section{RESUMO}

Objetivo: compreender a forma como os enfermeiros lidam com a autonomia do idoso na terminalidade da vida. Método: estudo qualitativo, exploratório, guiado pela Teoria Fundamentada nos Dados. Dez enfermeiros, oito médicos e 15 técnicos de enfermagem foram entrevistados entre novembro de 2016 e maio de 2017, em um hospital universitário, no Rio de Janeiro/Brasil. Resultados: os enfermeiros lidam com a autonomia do idoso em atendimento ao código de ética e exercem a liderança nas ações e interações para defender este direito, avaliando, orientando e ouvindo as preferências dos idosos; interatuando com a família; e compartilhando informações com a equipe de saúde. Considerações finais: a autonomia dos idosos deve ser assegurada no planejamento assistencial, tendo como base a comunicação centrada no paciente e desenvolvida no processo interacional entre os agentes envolvidos no cuidado. É preciso fomentar a discussão sobre as Diretivas Antecipadas de Vontades e sobre os princípios dos cuidados paliativos.

Descritores: Enfermagem; Autonomia Pessoal; Cuidados Paliativos na Terminalidade da Vida; Direitos dos Idosos; Doença Crônica; Hospitalização.

\section{RESUMEN}

Objetivo: comprender la forma en que los enfermeros se ocupan de la autonomía del anciano en relación con el fin de la vida. Método: estudio cualitativo, exploratorio, guiado por la Teoría Fundamentada en los Datos. Diez enfermeros, ocho médicos y 15 técnicos de enfermería fueron entrevistados entre noviembre de 2016 y mayo de 2017, en un hospital universitario, en Río de Janeiro/Brasil. Resultados: los enfermeros lidian con la autonomía del anciano en atención al código de ética y ejercen el liderazgo en las acciones e interacciones para defender este derecho, evaluando, orientando y escuchando las preferencias de los ancianos; interactuando con la familia; y compartiendo información con el equipo de salud. Consideraciones finales: la autonomía de los ancianos debe ser asegurada en la planificación asistencial, teniendo como base la comunicación centrada en el paciente y desarrollada en el proceso interacional entre los agentes involucrados en el cuidado. Es necesario fomentar la discusión sobre las Diretivas Antecipadas de Vontades (Directivas Anticipadas de Voluntades) y sobre los principios de los cuidados paliativos. Descriptores: Enfermería; Autonomía Personal; Cuidados Paliativos la Final de la Vida; Derechos de los Ancianos; Enfermedad Crónica; Hospitalización. 


\section{INTRODUCTION}

As the population ages, chronic noncommunicable diseases (CNCD) account for approximately $70 \%$ of the world's deaths annually ${ }^{(1)}$. Such diseases are associated with the clinical syndrome in the elderly, which results in physiological impairment, with increased hospitalizations and length of stay in health institutions. It is worth noting that interventions to control CNCD require high financial resources, specialized health services, palliative care provision, and training of health professionals ${ }^{(2)}$.

This reality affects the knowledge area of Nursing, since, once hospitalized, the elderly with CNCD suffer impact on quality of life and self-care capacity. Thus, the elderly need assistance with a high degree of dependence on the nursing team, as well as advocates for the preservation of their autonomy ${ }^{(3)}$.

Autonomy can be understood as a very personal right expressed in the capacity to make decisions, that is, in the freedom that people have to act and make their own decisions, according to their values and, consequently, decide what they think is best for them. Although the elderly are dependent, the right to autonomy must be guaranteed, since there is no relation between the need for care and the person's ability to take decisions about his own life ${ }^{(4-5)}$.

Although all have rights and duties according to the civil order, it is necessary to reflect on the right of autonomy under the bias of uncontested self-determination. Since people need to be understood in the context in which they are inserted, setting the precedent for shared decision-making, since there is no absolute right ${ }^{(5)}$.

Age is not a factor that incapacitates the person to personally perform the acts of civil life, such as deciding about life itself and death. However, frailties imposed by the disease and hospitalization, relations of power based on the scientific knowledge of Medicine and the domination of the biomedical curativist paradigm can generate situations in which the right to the elderly's autonomy is violated. Thus, as a health team member, the nurse can gather elements that favor the creation of links and the development of actions and interactions in the scope of care management to defend the elderly's autonomy ${ }^{(6-7)}$.

\section{OBJECTIVE}

To understand how nurses deal with the elderly's autonomy at the end of life.
Chart 1 - Presentation of sample groups, Rio de Janeiro, Brazil, 2017

\begin{tabular}{|c|c|c|c|c|}
\hline Groups & Participants & $\begin{array}{l}\text { Inclusion } \\
\text { criteria }\end{array}$ & $\begin{array}{c}\text { Exclusion } \\
\text { criteria }\end{array}$ & $\begin{array}{c}\text { Generating } \\
\text { question }\end{array}$ \\
\hline $\begin{array}{l}1^{\text {st }} \text { Sample } \\
\text { Group }\end{array}$ & Ten nurses & \multirow{3}{*}{$\begin{array}{l}\text { Having } \\
\text { employment } \\
\text { relationship } \\
\text { with the } \\
\text { institution } \\
\text { and minimum } \\
\text { experience of } \\
\text { six months in } \\
\text { medical clinic } \\
\text { wards. }\end{array}$} & \multirow{3}{*}{$\begin{array}{l}\text { Being away } \\
\text { from work for } \\
\text { any reason } \\
\text { during data } \\
\text { collection. } \\
\text { Acting in } \\
\text { exclusively } \\
\text { administrative } \\
\text { positions. }\end{array}$} & \multirow{3}{*}{$\begin{array}{l}\text { What } \\
\text { do you } \\
\text { understand } \\
\text { by the } \\
\text { elderly's } \\
\text { autonomy } \\
\text { at the end } \\
\text { of life? }\end{array}$} \\
\hline $\begin{array}{l}2^{\text {nd }} \\
\text { Sample } \\
\text { Group }\end{array}$ & $\begin{array}{l}\text { Eight doctors, being a } \\
\text { clinical responsible and } \\
\text { seven medical residents }\end{array}$ & & & \\
\hline $\begin{array}{l}3^{\text {rd }} \text { Sample } \\
\text { Group }\end{array}$ & 15 nursing technicians & & & \\
\hline
\end{tabular}

\section{METHOD}

\section{Ethical aspects}

The ethical aspects of research with human beings were respected, in compliance with Resolution 466/2012 of the National Health Council. Thus, the research project was approved by the proponent and co-participating institutions, respectively, Escola de Enfermagem Anna Nery and "Clementino Fraga Filho" University Hospital. All participants received information about the research and signed the Free and Informed Consent Term. Anonymity was ensured, with interview cut-outs identified by alphanumeric codes.

\section{Methodological framework}

The Grounded Theory (GT) was applied, based on the precepts from the Straussian School. With the GT, it is sought to unveil the understanding of the multiple phenomena of nursing team's performance setting from elements such as meanings, opinions, values and perceptions, and thus to meet the requisites of the object of study ${ }^{(8)}$.

\section{Type of study}

This is a qualitative, exploratory study.

\section{Study setting}

Data were collected in medical clinic wards of a university hospital in the city of Rio de Janeiro, Brazil, between November 2016 and May 2017.

\section{Collection and organization of data}

The analytical process' ability to target different sample groups is among the principles of GT development based on hypotheses that arise during data collection and analysis. When they arise, these new sample groups allow us to understand the rooting of the phenomenon investigated from other perceptions or meanings that directly influence the theorization of the research phenomenon. This possibility occurs because, in GT, data are collected and analyzed simultaneously. Thus, in addition to the group of nurses, two other sample groups were constructed, presented in Chart 1. 
Data saturation was discussed among researchers, whereas the categories were constructed with theoretical depth so as to be able, together, to explain the phenomenon investigated. In addition, the GT analytical process allows some resources to evaluate data theoretical density, in spite of even weighing saturation.

\section{Data analysis}

Data were analyzed by two researchers, independently. No divergences were identified and no analysis of a third researcher was necessary. Coding steps were followed by open coding, axial coding and integration. These steps highlight the analytical process of the information in the GT, which occurs from data division, conceptualization and correlation ${ }^{(8)}$.

In open coding, transcribed interviews raw data are analyzed line by line in the microanalysis, generating preliminary codes. In axial coding, preliminary codes are grouped by similarity, forming conceptual codes. Such codes may form subcategories which will then be grouped into categories representing concepts. In the last stage of integration, the paradigmatic model is applied to reveal the central category or central phenomenon of the study ${ }^{(8)}$.

The paradigmatic model is composed of the following elements: conditioning factors, action-interaction strategies and consequences. Conditioning factors aim to answer the questions about why, when and how things happen, and to evidence the reasons and explanations provided by participants to justify their actions (action/interaction) in the face of what happened. Action-interaction strategies comprise people's responses to particular problems, challenges or objectives. These responses result from the meanings attributed to them after perceptions about certain situations. Consequences can be understood as the actual results or expectations of certain actions ${ }^{(8)}$.
It should be noted that the coding generated three categories. However, considering the scope and importance of possible actions-interactions that can be implemented by the nurse to defend the elderly's autonomy, it was detailed, in this section, only a category referring to the paradigmatic component actionsinteractions strategies. This category gathers the ways individuals deal with certain situations, in this case, the elderly's autonomy and what people do to solve certain problems that emerge in the social context in which they are inserted.

With regard to the results theoretical validation, it is emphasized that the constant return to data using the constant comparison method is in itself one of the possibilities of validation.

\section{RESULTS}

Regarding the professional profile of participants, among nurses, the mean age was 39 years. The mean time in the sector was four years and the experience in palliative care was seven years. Eight nurses have Post-Graduate Degree. Among doctors, the mean age was 31 years. The mean time of performance in the sector and experience in palliative care was four years. Among nursing technicians, the mean age was 45 years. The mean time in the sector and experience in palliative care was seven years.

Regarding coding and systematic analysis of data, the category entitled "Establishing actions and interactions to defend the elderly's autonomy in palliative care at the end of life". This category represents the element of action-interaction strategies of the paradigmatic model, which contributed to the definition of the following central phenomenon: articulating elements of nursing and profile developed in its exercise in hospital care to defend the elderly's autonomy at the end of life.

This category consists of four subcategories presented in Chart 2.

Chart 2 - Presentation of raw data and main conceptual codes of subcategories, Rio de Janeiro, Brazil, 2017

\begin{tabular}{|c|c|}
\hline \multicolumn{2}{|c|}{ Subcategory 1: Interacting with the family to defend the elderly's autonomy } \\
\hline Raw data & Main conceptual codes \\
\hline $\begin{array}{l}\text { The main thing is the family oriented, participatory, who understands what is happening. Sometimes } \\
\text { you can promote the elderly's autonomy, but come the children who do not agree and want you to } \\
\text { do everything. (M8) } \\
\text { In communication with the family, we try to call those who are closest to a very open conversation; } \\
\text { we do not lie or omit things. (M5) } \\
\text { You have to see how the family feels at the moment. If it is very hopeful, we have to slow down. (M2) } \\
\text { Often, the family itself is a barrier because the elderly person is able to go to the bathroom, take the } \\
\text { bath, but the family wants to bathe in the bed. (T5) }\end{array}$ & $\begin{array}{l}\text { - Establishing a relationship of trust; } \\
\text { - Encouraging family participation; } \\
\text { - Speaking with the family based on the veracity of the } \\
\text { information; } \\
\text { - Evaluating what family members know about the } \\
\text { elderly's health status and what they want to know; } \\
\text { - Facing difficulties in the relationship with family } \\
\text { members. }\end{array}$ \\
\hline \multicolumn{2}{|c|}{ Subcategory 2: Interacting with the elderly autonomy to defend its autonomy } \\
\hline Raw data & Main conceptual codes \\
\hline $\begin{array}{l}\text { A good deed comes from caring, listening. Sometimes the patient does not want anything, } \\
\text { but knowing how to listen to what he has to tell you is an essential care for him [...]. We have } \\
\text { to respect the patient's decision, speaking his true condition, listening to his complaints. } \\
\text { Dialogue is essential, as it favors the elderly's autonomy. (E4) } \\
\text { I face the elderly's autonomy as relative because it depends on the level of consciousness and } \\
\text { the state it is. But, in my view, he who must decide what he wants. (E8) } \\
\text { It is necessary to give the patient the option to participate in the decisions about his life, but } \\
\text { if it is not clear to him what is happening and the options, he will not be able to express what } \\
\text { he wants. (E3) }\end{array}$ & $\begin{array}{l}\text { - Defending the elderly's autonomy; } \\
\text { - Dialoging with the elderly; } \\
\text { - Understanding the elderly's desires and their reasons; } \\
\text { - Assessing the elderly's level of consciousness and their } \\
\text { pathological condition; } \\
\text { - Relativizing the elderly's autonomy from their } \\
\text { condition; } \\
\text { - Creating conditions for the elderly to participate in } \\
\text { decision-making. }\end{array}$ \\
\hline
\end{tabular}




\begin{tabular}{|c|c|}
\hline \multicolumn{2}{|l|}{ Subcategory 3: Teamwork } \\
\hline Raw data & Main conceptual codes \\
\hline $\begin{array}{l}\text { I talk to the doctor that the patient commented that he no longer wants the treatment, that he } \\
\text { wants to surrender. Faced with this, the doctor asks for an opinion for a psychologist to talk to } \\
\text { him and confirm this position. (E5) } \\
\text { Through dialogue, the team will work well; and the view on the case is broadened. (E1) } \\
\text { With the multidisciplinary team, we have to first find out what they think, because they live with } \\
\text { us more than we do. I see the patient only on duty, but the nurse is with the patient all the time. } \\
\text { So they talk whether the patient is understanding or not. (M5) } \\
\text { Working almost always with the same team facilitates the sharing of decision-making with } \\
\text { nursing. (M8) } \\
\text { We discussed in round, we reaffirm in the passage of duty that, for that patient, it is only } \\
\text { measures of comfort and we inform the nursing and the social service after the decision has } \\
\text { been made. (M6) } \\
\text { Sometimes on duty there is a nutritionist who understands palliative care, supports autonomy, } \\
\text { and gives a little more comfort to the patient. (E8) } \\
\text { The elderly's autonomy will be easier if he has the opportunity to receive the visit of his doctor, } \\
\text { who follows him up for a long time, because he knows more about the patient than we do. (M7) }\end{array}$ & $\begin{array}{l}\text { - Subsidizing teamwork from sharing information; } \\
\text { - Dialoging with the other team professionals; } \\
\text { - Sharing the decision-making process; } \\
\text { - Centralizing in the doctor the decision-making } \\
\text { process; } \\
\text { - Seeking expert advice's opinion. }\end{array}$ \\
\hline \multicolumn{2}{|c|}{ Subcategory 4: Recognizing the nurse's leadership in defending the elderly's autonomy } \\
\hline $\begin{array}{l}\text { The nurse has more closeness to them than other professionals. Many things that the elderly do } \\
\text { not talk to the doctor they talk to the nurse. (M2) } \\
\text { I always ask the patient if he has informed himself what the doctor is giving him and most of the } \\
\text { time he says he does not. (E2) } \\
\text { I introduce myself by name, to be a reference for him as nurse on duty. Everything that will be } \\
\text { performed, I communicate to him on the proposal to be made like, for example, a peripheral } \\
\text { puncture. If he replies that he does not want to, I ask why to understand his arguments, for he } \\
\text { has his reasons. (E1) } \\
\text { When something makes it impossible for us to promote the elderly's autonomy, at first we have } \\
\text { the nurse, our immediate boss, to whom we pass on the situation that we do not agree and that } \\
\text { we think has to have an intervention. So the nurse is a reference in certain situations. (T1) } \\
\text { Most nurses, unfortunately, accept much of what is placed, perhaps because of work overload } \\
\text { or because they stop doing what can be done. (T6) }\end{array}$ & $\begin{array}{l}\text { - Having greater proximity to the elderly during } \\
\text { hospitalization; } \\
\text { - Having greater openness to dialogue with the elderly } \\
\text { and opportunity to understand their needs; } \\
\text { - Potentializing actions in defense of the elderly's } \\
\text { autonomy; } \\
\text { - Establishing a relationship of trust; } \\
\text { - Being a reference for the team and for the patient; } \\
\text { - Experiencing challenges to defend the elderly's } \\
\text { autonomy. }\end{array}$ \\
\hline
\end{tabular}

\section{DISCUSSION}

Interaction among nurses, other health team members and family of the elderly is an important action to promote their autonomy at the end of life, especially when hospitalized. Family nucleus plays a fundamental social role because, once participatory and integrated, it generates a feeling of brotherhood, security and dignity. In order for the family to play this role in the hospital, the health team must insert it into the caring process and consider it a unit of care, since it may require different needs $s^{(9)}$.

Communication is emphasized as an important work tool that, based on sensitivity and compassion, makes it possible to clarify doubts about the elderly's health in a simple and objective way ${ }^{(10)}$.

The study participants expressed concern that the information be transmitted in a clear way, based on truthfulness, respecting the capacity of understanding and the moment of acceptance of each person. It is necessary to pay attention to the elderly's emotional state and their relatives, who, depending on it, can interfere in the interpretation of the information. This requires caution on the part of the health team, since communication may need to be developed gradually over hospitalization.

Nurses play an important role in sharing information, since it occupies a strategic position in the hospitalization setting, acting as mediator between other team members, in order to meet the elderly's and their relatives' needs ${ }^{(11)}$.

Family, as a unit of care, needs to be instrumentalized. That is, it needs to be oriented and encouraged to participate actively in the care for the elderly, especially by the nurse who along with his team is responsible for the management of care 24 hours. However, it is necessary to train and encourage the participation of nurses so that they can mediate communication, including strategies such as family conferences ${ }^{(12-13)}$.

Situations of conflict and disagreement with the therapeutic plan are common when family members are not informed or are poorly informed. These situations may compromise their participation in the decision-making; consequently, in the interference in the elderly's autonomy, especially if there is cognitive deficit and transference of the guardianship ${ }^{(14-15)}$.

Care provided by the family is fundamental to provide the elderly's autonomy, even when patient is hospitalized and experiencing clinical situations that may increase their vulnerability. Thus, in order for the elderly's autonomy to be guaranteed, it is imperative that the team fosters mechanisms for securing compliance with this right. The national health policy that guides public and private services has principles and guidelines that guarantee the preservation of people's autonomy in defense of their physical and moral integrity ${ }^{(16-17)}$.

Care complexity in the process of death and dying; professional inability, institutional routines; the lack of theoretical-practical frameworks on palliative care; and the high workload cause a lack of time for information sharing, generating disagreements and inadequate understanding patient's diagnosis and prognosis, corroborating the difficulty of involving the family in the care context ${ }^{(15)}$.

Encouraging the participation of the elderly in the decisions about their treatments makes it possible to plan the care centered on the person, corroborating to put into practice a broad, 
interdisciplinary care approach that values their preferences. In Brazil, respect for autonomy and provision of information about clinical condition and treatment options are ethical and legal presuppositions provided in codes of ethics for health professionals ${ }^{(18)}$.

For nursing professionals, such prerogatives are contained in the Resolution of the Federal Nursing Council (Conselho Federal de Enfermagem) 564/2017, in articles 39 and 42 which include the professional duty to provide information on health treatment, respect and promote actions that promote the person's participation in treatment decisions. In this way, it is confirmed that patient's autonomy must be ensured in the care process, based on communication and developed in the interactional process among agents involved in care ${ }^{(16,18-19)}$.

Although communication and proposition of shared decisions meet the philosophy of palliative care, it is necessary to emphasize that there are possible barriers in health institutions to promote the elderly's autonomy. For example, we can find professional paternalism and unpreparedness to define diagnosis and prognosis, which contributes to generate false expectations and psychosocial commitments. Thus, unilateral and inadequate decision-making emerge from professional judgments that do not meet patients' wishes and that can distract them from the exercise of their autonomy ${ }^{(20)}$. It is fundamental to work as a team and to involve the elderly and their family in the decision-making process to avoid concentration of decision-making in the doctor.

In addition to the aforementioned barriers, frailty and vulnerability of the hospitalized elderly person with possible impairment of lucidity also interferes with the exercise of their autonomy, since this right is no longer recognized, which refers to the need for legal representation and the overlapping of the power of medicine.

Faced with biotechnological advances and the progressive complexity of care process due to population aging, it is imperative to guarantee the right to the elderly's autonomy so that they can decide what treatment they want according to their ethical, moral and religious values. As it is one of the principles of bioethics, autonomy aims to protect them against the misuse of futile therapeutic measures aimed at maintaining life, even if without quality.

Present in international treaties, such as the Universal Declaration on Bioethics and Human Rights of the United Nations Educational, Scientific and Cultural Organization, Science and Culture and in Brazilian legislation, such as the Estatuto do Idoso (Statute of the Elderly) and the Constitution of the Federative Republic of Brazil, principles of the elderly's autonomy and best interests are intended to ensure the right to opt for the health treatment more favorable, safeguarding their dignity.

It is confirmed in some passages of statements that patient has the right to autonomy, including deciding whether or not to stay hospitalized, as he is aware of the evolutionary process of his illness. However, this autonomy seems to be conditioned to certain factors; among them, their health condition and their cognitive ability to make decisions. With this, there are data that affirm that the autonomy is not an absolute right, since it must be shared between patient, professionals and relatives. Regarding the shared decision, patients need to be encouraged by the health team to play an active role in the decision-making process. Thus, you can express your values, needs, preferences and what you want to achieve with the proposed treatment.
It is important to establish the incentive for shared decisionmaking in institutions, at the heart of the systematization of care, identifying the barriers that may prevent the defense of the elderly's autonomy. In this context, nurses add fundamental importance since they have the possibility to promote communication in a clear way to identify circumstances threatening the elderly's autonomy and act informing them in order to make them an active agent in their treatment, as well as mediate and facilitate the team care planning ${ }^{(5,21)}$.

The elderly's passivity in the relations with doctors can be analyzed from the perspective of the social and cultural representation that medicine exerts in society. Doctor is viewed by the majority of the population as the professional who has knowledge about the body and is fully empowered to make the best decisions for patients. However, it is necessary to consider this relationship, since the sociocultural pressure of the doctor's role can hinder exchange of information, shared decision-making and exercise of the elderly's autonomy ${ }^{(22)}$.

Caring for patients at the end of life should be provided from an interdisciplinary perspective. Each professional category should offer its own knowledge and technologies, establish communication with each other and, in this way, exchange information about patients' clinical condition, so that the best treatment can be offered that meet their expectations. Thus, the importance of interactive actions among caregivers is confirmed. Regarding the nurses' performance, because they are closer to patients and their families, through clinical reasoning, the Nursing Process and communication as a work tool, they have mechanisms to promote interlocution among health team, as well as contribute to patient-centered decision-making process ${ }^{(23)}$.

The nurse when transmitting certain information and promotes the dialogue with medical staff, is validating teamwork as an assurance mechanism to defend the elderly's autonomy. The dialogue in a team enlarges the possibilities of care, generating new care behaviors and the performance of professionals who, until then, were not included in the care planning, for example, through issuance of opinions. This is the case in the case of experts participation in several areas, such as oncology, geriatrics and palliative care.

Care planning is also qualified when any on-duty staff member has expertise in palliative care, which contributes to the design of goals to promote comfort and quality of life. Thus, given the difficulties and adversities already highlighted to share decisions, communicate bad news and defend principles, such as autonomy, the importance of specific knowledge in palliative care.

In Brazil, the nurse's role in defense of patients' rights, with emphasis on autonomy, is not adequately consolidated. However, due to the profession's characteristics with philosophical and humanistic bases, as well as the professional profile that can be developed in the practice of care, nurses have many opportunities and methodological tools. For example, the Nursing Process, to evaluate patients in an individualized way, identify different responses and needs and safeguard their rights, providing support and information.

However, hospitalization of the elderly, given their even more potent fragilities, can trigger feelings of inability to make their own decisions. In this way, dependence on one's own care and feelings of insecurity entails the de-personalization of the elderly. 
But, nurses' small attitudes, such as the exercise of listening, can raise the protagonist status of the elderly in their care.

Although not necessarily the nurse can be the representative figure of the defender of the elderly, in certain situations, in compliance with the ethical precepts in the professional exercise, must defend it, thus protecting their autonomy ${ }^{(24-25)}$.

The elderly's autonomy defense by the nurse comprises a special and specific professional duty that is part of the moral presuppositions, capable of enhancing social visibility of the profession. But, on the other hand, it can be hampered in the realities where there is risk of functional overload due to the polarization of multiple tasks and the deficit of human resources.

Nurses need specific skills, motivation and professional commitment to defend the elderly's autonomy. However, in promoting this defense, the nurse may have conflicts with other health professionals. Therefore, it is necessary to maintain an assertive behavior, to have diplomacy and ability to communicate and negotiate, since its actions in favor of the elderly can generate confrontation of opinions, interests and false interpretations.

Based on the professional profile developed in the care practice, it is understood that the defense action is interpersonal in nature and depends on the degree of the relationship established between nurse and patient. However, coping with barriers to this action can trigger a sense of impotence and moral outrage ${ }^{(24-25)}$. Among barriers, in addition to the clinical condition of the elderly, there is a lack of institutional support, lack of power, lack of training to perform such activity, lack of time due to multiple tasks and the threat of punishment and loss of employment.

The elderly's autonomy defense by the nurse must also be discussed under the prism of the risk of paternalism, especially when the elderly present changes in the level of consciousness and can no longer express their desires. In this case, it is necessary to disseminate knowledge about the "Living Wills" Health Care Directives as a tool that can be used by the elderly to express their desires about the end of life in situations that can no longer respond for their actions ${ }^{(26-27)}$.

The defense exercised by the nurse represents an indicator of the quality of nursing services. In taking on this role, nurses regard patients as human endowed with their beliefs. This belief distances them from a merely technical position in the moments that need to elucidate some doubt or even in the approaches of hospital routine ${ }^{(25,28)}$.

\section{Study limitations}

It is recognized as a limitation of this study the fact that a single research setting was explored, although it is a large general hospital. Another limiting aspect refers to the sample groups composition, since they did not participate in the study: family members, other health professionals or even the elderly. With this, there is a need for new scientific productions on the theme including new participants.

Although not a limitation, since the method does not provide for the need to return data to participants, it is important to execute other forms of validation of results that can count on the group's evaluation or part of the group of participants of the research. It seeks representativeness of the investigated reality and possible applicability to other realities.

\section{Contributions to the fields of Nursing, Health and Public Policy}

To provide greater visibility of the Brazilian nurse's role in the field of health advocacy and contribute to the quality of the service provided; to defend the elderly's autonomy, which is key element in palliative care; to encourage discussions to meet international guidelines and public policies regarding the need for palliative care, especially for the elderly with CNCD.

\section{FINAL CONSIDERATIONS}

The elderly's autonomy at the end of life refers to their participation in decision-making on issues inherent in their care, in respect of dignity. However, several situations can violate it, such as disease and hospitalization fragility.

As they remain close to patient and their family, nurses can play an important role in defending the elderly's autonomy by establishing effective communication and guidance on care. Its position in the institutional organization chart and professions characteristics confer privileges to establish actions and interactions within the scope of nursing and health team, elderly and their families, to carry out individualized care based on bioethical and humanistic principles.

Thus, in compliance with the professional code of ethics, nurses can intervene to protect the elderly's autonomy in situations of vulnerability. In other words, when they unable to express their needs, beliefs and values, such as, for example, the situation of CNCD at an advanced stage and in care at the end of life. Autonomy is a fundamental element for the implementation of palliative care, requiring expanded discussions about this principle and the sharing of decision-making, since they imply in nursing practice.

\section{FUNDING}

This study was carried out with the support of the Coordination for Improvement of Higher Education Personnel - Brazil (CAPES - Coordenação de Aperfeiçoamento de Pessoal de Nível Superior) - Financing Code 001.

\section{REFERENCES}

1. Castro VC, Borghi AC, Mariano PP, Fernandes CAM, Mathias TAF, Carreira L. Hospitalization profile of elderly within the unified health system. Rev RENE [Internet]. 2013 [cited 2016 Jun 07];14(4):791-800. Available from: http://www.periodicos.ufc.br/rene/article/view/3548/2788

2. Malta DC, Bernal RTI, Lima MG, Araújo SSC, Silva MMA, Freitas MIF, et al. Noncommunicable diseases and the use of health services: analysis of the National Health Survey in Brazil. Rev Saude Publica. 2017;51(Suppl 1):4s. doi: 10.1590/s1518-8787.2017051000090 
3. Kernkamp CL, Costa CKF, Massuda EM, Silva ES, Yamaguchi MU, Bernuci MP. Perfil de morbidade e gastos hospitalares com idosos no Paraná, Brasil, entre 2008 e 2012. Cad Saúde Pública. 2016;32(7):e00044115. doi: 10.1590/0102-311X00044115

4. Valcarenghi RV, Lourenço LFL, Siewert JS, Alvarez AM. Nursing scientific production on health promotion, chronic condition, and aging. Rev Bras Enferm. 2015;68(4):618-25. doi: 10.1590/0034-7167.2015680419i

5. Wilson F, Ingleton C, Gott M, Gardiner C. Autonomy and choice in palliative care: time for a new model? J Adv Nurs. 2013;70(5):1020-29. doi: 10.1111/jan.12267

6. Felix ZC, Batista PSS, Costa SFG, Lopes MEL, Oliveira RC, Abrão FMS. Nursing care in terminality: compliance with principles of bioethics. Rev Gaúcha Enferm. 2014;35(3):97-102. doi: 10.1590/1983-1447.2014.03.46405

7. Khoury HTT, Sá-Neves AC. Percepção de controle e qualidade de vida: comparação entre idosos institucionalizados e não institucionalizados. Rev Bras Geriatr Gerontol. 2014;17(3):553-65. doi: 10.1590/1809-9823.2014.13012

8. Corbin JM, Strauss A. Basics of qualitative research: techniques and procedures for developing Grounded Theory. 14th ed. Thousand Oaks: SAGE; 2014.

9. Bautista Rodríguez LM, Arias Velandia MF, Carreño Leiva ZO. Percepción de los familiares de pacientes críticos hospitalizados respecto a la comunicación y apoyo emocional. Rev Cuid. 2016;7(2):1297-309. doi: 10.15649/cuidarte.v7i2.330

10. Andrade CG, Costa SFG, Lopes MEL. Cuidados paliativos: a comunicação como estratégia de cuidado para o paciente em fase terminal. Cien Saude Colet. 2013; 18(9):2523-30. doi: 10.1590/S1413-81232013000900006

11. Gibaut MAM, Hori LMR, Freitas KS, Mussi FC. Comfort of the patient's family in an Intensive Care Unit related to welcoming. Rev Esc Enferm USP. 2013;47(5):1114-21. doi: 10.1590/S0080-623420130000500015

12. Moir C, Roberts R, Martz K, Perry J, Tivis LJ. Communicating with patients and their families about palliative and end-of-life care: comfort and educational needs of nurses. Int J Palliat Nurs. 2015;21(3):109-12. doi: 10.12968/ijpn.2015.21.3.109

13. Silva SR, Trindade GSS, Paixão GPN, Silva MJP. Family conference in Palliative care: concept analysis. Rev Bras Enferm [Internet]. 2018;71(1):206-13. doi: 10.1590/0034-7167-2016-0055

14. Warnock C, Buchanan J, Tod AM. The difficulties experienced by nurses and healthcare staff involved in the process of breaking bad news. J Adv Nurs. 2017;73(7):1632-45. doi: 10.1111/jan.13252

15. You JJ, Downar J, Fowler RA, Lamontagne F, Ma IW, Jayaraman D, et al. Barriers to goals of care discussions with seriously ill hospitalized patients and their families: a multicenter survey of clinicians. JAMA Intern Med. 2015;175(4):549-56. doi: 10.1001/jamainternmed.2014.7732

16. Bélanger E, Rodríguez C, Groleau D, Légaré F, MacDonald ME, Marchand R. Patient participation in palliative care decisions: an ethnographic discourse analysis. Int J Qual Stud Health Well-being. 2016;22(11):32438. doi: 10.3402/qhw.v11.32438

17. Tomaschewski-Barlem JG, Lunardi VL, Barlem ELD, Ramos AM, Figueira AB, Fornari NC. Nursing beliefs and actions in exercising patient advocacy in a hospital context. Rev Esc Enferm USP. 2015;49(5):806-12. doi: 10.1590/S0080-623420150000500015

18. Conselho Federal de Enfermagem (Cofen). Resolução n 564, de 6 de novembro de 2017. Aprova o novo código de ética dos profissionais de enfermagem [Internet]. Brasília: Cofen, 2017 [cited 2018 Jan 10]. Available from: http://www.cofen.gov.br/resolucao-cofenno-5642017_59145.html

19. Nogario ACD, Barlem ELD, Tomaschewski-Barlem JG, Lunardi VL, Ramos AM, Oliveira ACC. Nursing actions in practicing inpatient advocacy in a burn unit. Rev Esc Enferm USP. 2015;49(4):579-86. doi: 10.1590/S0080-623420150000400007

20. Hoerger M, Epstein RM, Winters PC, Fiscella K, Duberstein PR, Gramling R, et al. Values and options in cancer care (VOICE): study design and rationale for a patient-centered communication and decision-making intervention for physicians, patients with advanced cancer, and their caregivers. BMC Cancer. 2013;13:188. doi: 10.1186/1471-2407-13-188

21. Hahlweg P, Didi S, Kriston L, Härter M, Nestoriuc Y, Scholl I. Process quality of decision-making in multidisciplinary cancer team meetings: a structured observational study. BMC Cancer. 2017;17:772. doi: 10.1186/s12885-017-3768-5

22. Silva JLCL, Silva TCM, Alencar LCA. O paciente e a vivência da visita médica à beira do leito. Rev Bras Educ Med. 2016;40(4):704-12. doi: 10.1590/1981-52712015v40n4e01572015

23. Carvalho EC, Oliveira-Kumakura ARS, Morais SCRV. Clinical reasoning in nursing: teaching strategies and assessment tools. Rev Bras Enferm [Internet]. 2017;70(3):662-8. doi: 10.1590/0034-7167-2016-0509

24. Cole C, Wellard S, Mummery J. Problematizing autonomy and advocacy in nursing. Nurs Ethics. 2014;21(5):576-82. doi: $10.1177 / 0969733013511362$

25. Hanks RG. Barriers to nursing advocacy: a concept analysis. Nurs Forum. 2007;42(4):171-7. doi: 10.1111/j.1744-6198.2007.00084.x

26. McSteen $\mathrm{K}$, Peden-McAlpine $\mathrm{C}$. The role of the nurse as advocate in ethically difficult care situations with dying patients. J Hosp Palliat Nurs. 2006;8(5):259-269. doi: 10.1097/00129191-200609000-00011

27. Zomorodi M, Foley BJ. The nature of advocacy vs. paternalism in nursing: clarifying the 'thin line.' J Adv Nurs. 2009;65(8):1746-52. doi: $10.1111 /$ j.1365-2648.2009.05023.x

28. Tomaschewski-Barlem JG, Lunardi VL, Barlem ELD, Ramos AM, Silveira RS, Vargas MAO. How have nurses practiced patient advocacy in the hospital context? a Foucaultian perspective. Texto Contexto Enferm. 2016;25(1):e2560014. doi: 10.1590/0104-0707201600002560014 